\title{
PEMBUATAN WEBSITE KAMPUNG KUBANG KEMIRI KELURAHAN SUKAWANA KECAMATAN SERANG MENUJU KAMPUNG KONVEKSI DIGITAL
}

\author{
Ratu Erlina Gentari 1, Denny Kurnia 2, Lina Marliana Dewi ${ }^{3}$ \\ ${ }^{1}$ Manajemen, Universitas Serang Raya \\ ${ }^{2}$ Akuntansi, Universitas Serang Raya \\ ${ }^{3}$ Akuntansi, Universitas Serang Raya

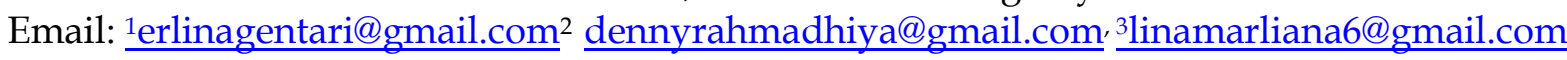

\begin{abstract}
Abstrak
Dunia bisnis semakin maju. Pemasaran merupakan kunci kesuksesan suatu usaha baik bidang jasa maupun produk. Di era modernisasi pemasaran juga tidak dapat hanya dilakukan secara konvensional dengan melakukan pemasaran di lapangan tetapi kita juga harus mulai menggunakan pemasaran modern dengan berbasis online. internet menawarkan kesempatan untuk menyediakan lingkungan baru yang inovatif dan dapat mningkatkan pemasaran produk.

Pada Era digital saat ini yang memberikan peluang baru, pengaruh baik dan kontribusi positif dalam peningkatan kualitas pada proses kegiatan pemasaran menjadi tantangan bagi masyarakat Kampung Kubang Kemiri Kelurahan Sukawana Kecamatan Serang untuk meningkatkan perekonomian melalui pembuatan website dan menuju kampung digital. Untuk itu dalam rangka meningkatkan pemasaran produk dari konveksi guna mengembangkan dan meningkatkan profesionalisme dalam mengintegrasikan teknologi pada pemasaran konveksi merupakan upaya yang mutlak harus dilakukan oleh masyarakat Kubang Kemiri untuk Fokus ke pembuatan website yang bertujuan untuk meningkatkan perekonomian masyarakat kampung kubang kemiri kelurahan sukawana yang rata rata masyarakatnya berwirausaha dalam bidang konveksi. Adapun target khusus program ini adalah diharapkan (1) UKM dapat meningkatkan omset dan nilai asset konveksi (2) dapat meningkatkan kualitas produk dan desain produk konveksi semakin variatif (3) UKM dapat memiliki SDM yang trampil dalam pembuatan website (4) UKM dapat meningkatkan kualitas produk dan meningkatkan produksi, pemasaran melalui pembuatan website (5) UKM dapat memajukan dan mengikuti perkembangan digital yang memberikan peluang baru, pengaruh baik dan kontribusi positif dalam peningkatan kualitas pada proses kegiatan pemasaran hasil konveksi. Hal tersebut menjadi tantangan bagi masyarakat kampung kubang kemiri kelurahan sukawana kecamatan serang untuk meningkatkan perekonomian melalui pembuatan website dan menuju kampung digital.
\end{abstract}

Kata Kunci: Program Kemitraan Masyarakat, Pembuatan Website, Kampung Konveksi Digital

\section{Abstract}

The business world is getting more advanced. Marketing is the key to success of a business both in services and products. In the modernization era marketing can not only be done conventionally by doing marketing in the field but we also have to start using modern marketing based online. The internet offers the opportunity to provide an innovative new environment and can improve product marketing.

In the current digital era that provides new opportunities, good influence and positive contribution in improving quality in the process of marketing activities is a challenge for the people of Kampung Kubang Kemiri, Sukawana Village, Serang District to improve the economy through website creation and towards digital villages. For that reason, in order to improve the marketing of products from convection to develop and improve professionalism in integrating technology in convection marketing, it is an absolute effort that must be made by the people of Kubang Kemiri to focus on 
creating websites that aim to improve the economy of the people of the village of Kubang Kemiri, Kelurahan, Sukawana, which are the average of the people. entrepreneurship in the field of convection. The specific target of this program is expected (1) SMEs can increase turnover and value of convection assets (2) can improve product quality and increasingly varied convection product designs (3) SMEs can have skilled human resources in making websites (4) SMEs can improve quality products and increasing production, marketing through website creation (5) SMEs can advance and follow digital developments that provide new opportunities, good influence and positive contributions in improving quality in the process of marketing the products of convection. This is a challenge for the people of the village of Kubang Kemiri, Sukawana, Serang, to improve the economy through website development and towards a digital village.

Keywords: Community Partnership Program, Website Creation, Digital Convection Village

\section{PENDAHULUAN}

Desa sukawana terletak di Kecamatan Serang Kota Serang Banten, Kelurahan Sukawana terdiri dari 7 kampung yaitu Kebanyakan Wetan, Kebanyakan Kulon, Kebanyakan Tegal, Kalisalak, Kubang Kemiri, Sambi Growong, Sentul. Jumlah penduduk Desa Sukawana 5.042 jiwa dengan total 3.310 kartu keluarga.Kubang kemiri terletak di Desa Sukawana Kecamatan Serang Kota Serang Banten, rata rata warga Desa Sukawana bekerja di bidang industry konveksi dan beberapa warga sudah memiliki usaha konveksi yang cukup besar dan mempunyai karyawan.. Kegiatan pengabdian masyarakat PKM ini bekerjasama dengan warga masyarakat Kubang Kemiri sebagai mitra.

Kubang Kemiri Desa Sukawana sebagai mitra kegiatan pengabdian ini memiliki lokasi yang lebih mudah dijangkau dengan kendaraan angkutan umum $\pm 11,4 \mathrm{Km}$ dari Universitas Serang Raya dan $\pm 8,3 \mathrm{Km}$ dari pusat kota Serang. Secara umum Kampung Kubang Kemiri masih bisa terjangkau, dengan fasilitas terbatas dan belum optimal. Keterbatasan dan ketidakoptimalan ini mengakibatkan kemampuan warga dalam teknologi, dalam mengembangkan ide kreatif dan inovatif dalam pemasaran konveksi terbatas sehingga berdampak pada output dan pendapatan keluarga. Kurangnya kegiatan pelatihan untuk mengembangkan keterampilan dalam membuat website khususnya yang memanfaatkan teknologi menyebabkan tidak terasah dan tidak berkembangnya keahlian dalam pembuatan website. Hasil wawancara singkat dengan beberapa warga kubang kemiri terungkap bahwa frekuensi dalam mengikuti pelatihan pembuatan website masih sangat minim. Hal tersebut menjadikan tidak up to date terhadap perkembangan informasi khususnya mengenai website yang dapat dimanfaatkan. Kurangnya dukungan pendanaan disebutkan pula sebagai salah satu faktor yang melatarbelakangi masalah tersebut.

Penggunaan teknologi dalam dekade terakhir ini sangat pesat, tidak terkecuali dalam pemasaran produk hasil konveksi. Pembuatan Website berbantuan teknologi dapat membantu warga dalam memasarkan produknya.. Dengan cara mengintegrasikan teknologi ke dalam proses pengajaran dan pembelajaran pembuatan website. diharapkan dapat meningkatkan kemampuan warga dalam memahami ide-ide kompleks dan mampu mengonstruksi pemecahan masalah pembuatan website, Dengan memperhatikan dan mempertimbangkan kondisi dan situasi warga kubang kemiri baik dari lokasi yang mayoritas jauh dari pusat kota maupun belum optimalnya dukungan kegiatan pengembangan kemampuan dan keterampilan pembuatan website melalui pelatihan khususnya dalam mengembangkan pembuatan website

Fungsi web desain sendiri bisa digunakan sebagai media komunikasi yang lebih menarik. Pada fungsi komunikasi dapat dilihat dari website 
yang memiliki nilai dinamis. Biasanya website ini dibuat menggunakan program website yang akan dilengkapi dengan fasilitas yang akan mendukung fungsi komunikasi yang ada. Salah satunya dengan menggunakan Web Design yang akan membuat pengunjung semakin tertarik untuk melihat. Pada fungsi informasi, maka saat menggunakan desain akan lebih menekankan kualitas konten supaya isi dapat tersampaikan dengan baik.Sedangkan pada fungsi entertainment website ini digunakan sebagai sarana yang dapat meningkatkan mutu presentasi. Terutama dalam website yang menyediakan promosi atau yang lainnya. Mulai dari game, film, music online dan yang lainnya.Untuk fungsi transaksi dapat dijadikan sebagai media bisnis yang baik. Karena dengan adanya desain website yang bagus, akan menarik banyak perusahaan, menghubungkan pada konsumen dan proses pemasarannya lebih mudah.Fungsi dan Kegunaan Website Fungsi atau makna dari dibuatnya sebuah website ini sangat beragam, mulai dari untuk media promosi, media pemasaran, media informasi, media pendidikan serta sebagai media komunikasi.Untuk prerkembangan website di Indonesia sendiri khususnya di desa sukawana begitu meluas dan tumpah ruah akan mirip pasar, mengapa bisa ? setiap kita terhubung ke dalam jaringan luas di dalam internet pasti kita menemukan apa yang disebut dengan website itu sendiri.Perubahan dan perkembangan di dunia IPTEK ini, tidak bisa dipungkiri sedikit banyak pasti mempengaruhi segala aspek kehidupan kita saat sekarang ini. Dengan kata lain, IPTEK adalah suatu hal yang wajib dan krusial bagi kehidupan manusia saat ini, dan untuk masa yang akan datang. Ada seorang ahli mengatakan bahwa, ilmu pengetahuan merupakan fondasi bagi teknologi sedangkan teknologi adalah tulang punggung pembangunan,Ilmu pengetahuan dan teknologi atau IPTEK merupakan segi yang tidak dapat dikesampingkan dari kehidupan dan kesejahteraan manusia. Disadari bahwa perkembangan ilmu pengetahuan dan teknologi dunia berkembang sangat cepat, dan perkembangan ini harus disadari adanya dan diketahui arahnya. Oleh karena itu, IPTEK harus dijadikan suatu alat pendukung untuk mengantarkan manusia ke kehidupan yang lebih baik, bukan dijadikan suatu polemik yang sudah banyak disalah gunakan perannya oleh oknum-oknum yang tidak bertanggung jawab yang mensia-siakan fungsi IPTEK itu sendiri. Pada akhirnya, hanya orang-orang yang mempunyai sifat peduli dan intelejensi yang cukup tinggi yang bisa memanfaatkan fungsi IPTEK untuk memberikan kehidupan yang lebih baik untuk mereka. Dengan perpaduan tersebut, IPTEK dan kemampuan sama Strategi Pemasaran yang tepat diperlukan untuk lebih mengenalkan produksi konveksi Kubang Kemiri menjadi produk unggulan daerah. Perkembangan teknologi e-commerce saat ini tepat untuk diimplementasikan guna menarik para pembeli.

\section{RUMUSAN MASALAH}

Perumusan masalah (problem statement) dalam kegiatan pengabdian ini adalah: bagaimana merencanakan pembuatan website untuk meningkatkan pemasaran hasil produk konveksi berbasis E-commerce pada kerajinan konveksi?

1.Merencanakan pemasaran berbasis Ecommerce pada produk konveksi Kampung Kubang Kemiri.

2.Membantu menyediakan fasilitas pemasaran melalui media online.

1. Memberikan pelatihan ketrampilan pengelolaan aplikasi e-commerce untuk pemasaran produk konveksi Kubang Kemiri.

2. UKM dapat meningkatkan omset dan nilai asset konveksi

3. Dapat meningkatkan kualitas produk dan desain produk konveksi semakin variatif

4. UKM dapat memiliki SDM yang terampil dalam pembuatan website 
5. UKM dapat meningkatkan kualitas produk dan meningkatkan produksi dan pemasaran melalui website

6.

UKM dapat
mengikuti
perkembangan digital
yang memberikan
peluang baru

\section{LUARAN YANG DIHARAPKAN}

Luaran yang diharapkan dari kegiatan ini adalah :

Jasa Perencanaan Pembuatan Aplikasi E-commerce untuk pemasaran (misalnya: website), Desain Aplikasi E-commerce ,Pelatihan pengelolaan Aplikasi Ecommerce dan Artikel Ilmiah

\section{MANFAAT KEGIATAN}

Manfaat yang ingin dicapai dari kegiatan ini adalah :

1.Bagi Masyarakat sasaranDapat mengembangkan skala produksi dari pasar lokal ke internasional

2.Bagi Pelaksana kegiatan dapat mengimplementasikan pembelajaran aplikasi e-commerce untuk pemasaran ekspor

\section{Permasalahan Mitra}

Melalui obesrvasi, survey lapangan dan wawancara dengan mitra kegiatan pengabdian, diketahui beberapa permasalahan yang disepakati oleh pihak mitra dan tim pelaksana pengabdian untuk diselesaikan, diantaranya yaitu:

1.Jangkauan teknologi yang terbatas sehingga warga kubang kemiri masih kekurangan akses informasi perkembangan terbaru khususnya mengenai website

2.Lemahnya kemampuan daya kreasi dan inovasi warga dalam pembuatan website.

3Mayoritas warga belum pernah mendapatkan kesempatan mengikuti pelatihan pemanfaatan teknologi pembuatan website.
4.Belum optimalnya kemampuan warga dalam pembuatan website

5.untuk meningkatkan kualitas pemasaran konveksi masih terbilang biasa bahkan cenderung rendah, namun terkendala oleh faktor-faktor utama seperti tidak adanya alokasi dana untuk kegiatan pelatihan

6.Keterampilan menjahit tidak merata yang menyebabkan tidak meratanya mutu jahitan sehingga mengecewakan konsumen

7.Hambatan dalam menjalankan dan mengembangkan usaha saat ini adalah masalah masih menggunakan konsep pemasaran sederhana dan jangkauan pemasaran masih sempit.

\section{METODE PELAKSANAAN}

Metode yang digunakan adalah Sosialisasi website yaitu pengenalan website dan praktik secara partisipasif.. Metode ini merupakan metode pelatihan dalam bidang pendidikan, perdagangan, kerajinan, pertanian, bisnis, dan lain-lain (Onyima, J. dkk., 2000). Pemagangan kerja dipandang sebagai salah satu metode yang efektif dalam menjadikan seseorang ahli dalam bidang yang ditekuni karena belajar langsung dari ahlinya (Horn, D., 2014). Sementara Participatory Learning Action merupakan bentuk baru dari metode pemberdayaan masyarakat yang sebelumnya lebih dikenal dengan 'Learning by Doing' atau belajar sambil bekerja (Phuyal, 2008; IIED, 2013). Participatory Learning Action merupakan proses belajar secara berkelompok yang dilakukan secara interaktif dalam suatu proses kerja (Appel dkk, 2012). Pelaksanaan kegiatan pengabdian ini akan dilaksanakan melalui tiga tahap yaitu tahap awal, tahap inti dan tahap akhir. Secara umum tahapan kegiatan pengabdian ini sebagai berikut:

1. Tahap awal. Kegiatan pada tahap ini meliputi (a) observasi dan survey lapangan dilakukan sebagai analisis awal untuk mendapat informasi mendalam dan menyeluruh mengenai 
permasalahan mitra dan mencari solusi yang dibutuhkan dan tepat sasaran; (b) kelengkapan administrasi dilakukan sebagai prosedur formal untuk melegalkan kegiatan pengabdian; dan (c) merancang kegiatan inti dan menyusun modul pelatihan yang sesuai dengan kebutuhan mitra dan sebagai solusi dari permasalahan yang dihadapi.

2. Tahap inti. Dalam tahap kedua ini, fokus kegiatan pengabdian dilakukan yaitu pendampingan dan bimbingan kepada mitra melalui serangkaian pelatihan. Ada lima kegiatan pelatihan yang akan diikuti oleh mitra, yaitu (a) Pelatihan; (b) sosialisasi; (c) pengenalan; (d) implementasinya pada pembuatan web site; dan (e) praktik pembuatan website.

3. Tahap akhir. Ada tiga kegiatan dalam tahap ini yaitu (a) evaluasi kegiatan yang akan dilakukan per kegiatan dan secara menyeluruh; (b) penyusunan laporan akhir; dan (c) publikasi hasil kegiatan pada jurnal/prosiding atau media masa

\section{HASIL DAN PEMBAHASAN}

Kegiatan pengabdian secara keseluruhan telah berjalan 100\% Berdasarkan uraian pada bab 3 mengenai metode pelaksanaan kegiatan pengabdian yang terdiri atas tiga tahap, maka hasil kegiatan akan dipaparkan per tahap kegiatan.

a. Kegiatan Tahap awal

Pada tahap awal kegiatan, ada tiga agenda utama yang dilakukan tim PKM yaitu (1) observasi dan survey lapangan; (2) kelengkapan administrasi; dan (3) merancang kegiatan inti dan menyusun modul pelatihan.

Kegiatan observasi dan survey lapangan dilakukan dua. Kegiatan obesrvasi dan survey lapangan ketika tahap pengajuan dilakukan sebagai (1) analisis awal untuk mendapat informasi mendalam dan menyeluruh mengenai permasalahan mitra dan (2) mencari solusi yang dibutuhkan dan tepat sasaran.

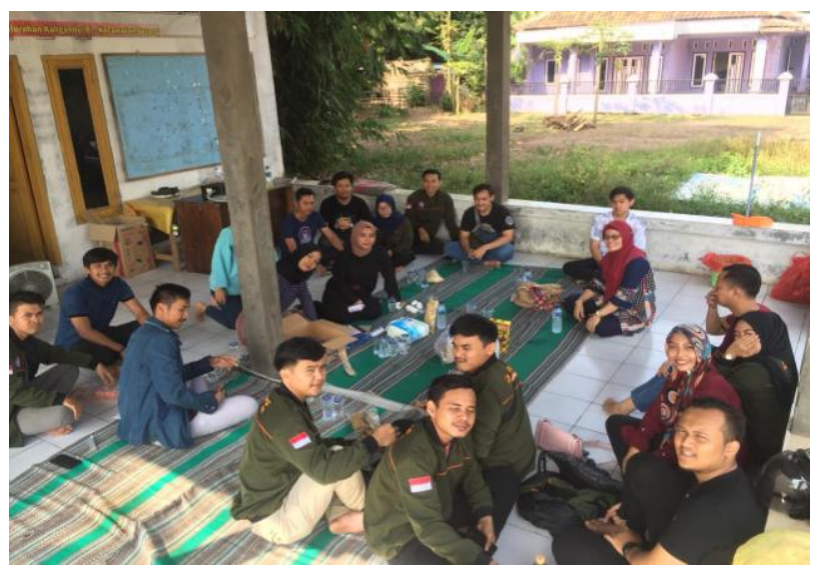

Tahap awal program PKM telah mencapai $100 \%$. Adapun hasil yang diperoleh pada tahap awal ini antara lain (1) jadwal fix kegiatan pengabdian baik kegiatan inti maupun kegiatan pendampingan, (2) modul pelatihan yang akan dijadikan panduan pelatihan pembuatan website.

b. Kegiatan Tahap inti

Fokus pada tahap inti ini adalah kegiatan terpusat dan kegiatan pendampingan- bimbingan kepada masyarakat kubang kemiri dalam pembuatan website

c. Kegiatan Tahap akhir

Pada tahap ini dilakukan evaluasi dengan mengolah data yang diperoleh pada tahap inti melalui observasi, penyebaran angket dan wawancara. Adapun hasil pengolahan data berupa (1) persentase hasil observasi (2) persentase hasil angket pemahaman, dan (3) keefektifan kegiatan pelati 


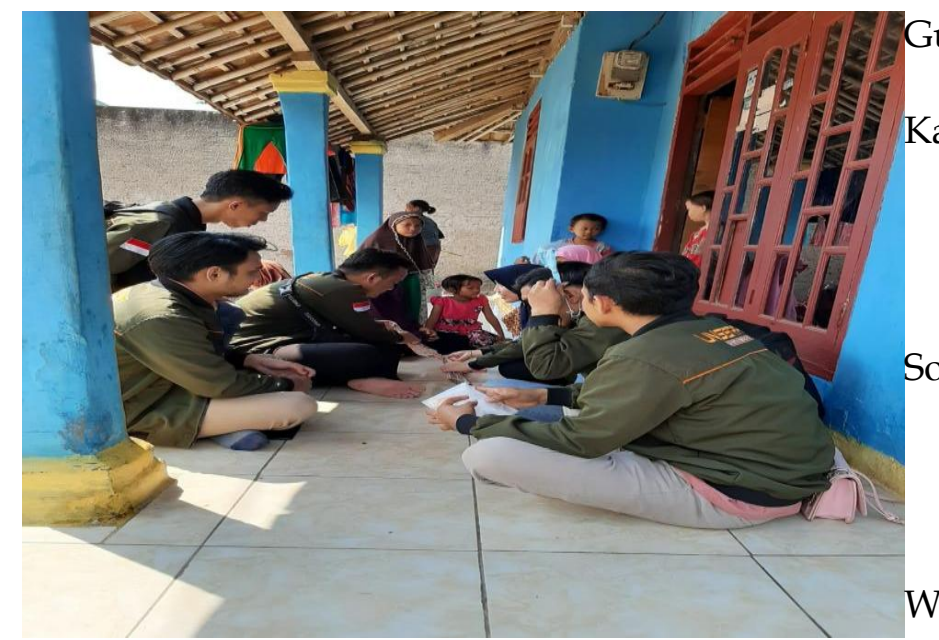

Ucapan Terima Kasih

Terima kasih kepada MASYARAKAT

Kubang Kemiri Kelurahan Sukawana, Lurah sukawana dan Camat kota Serang yang telah bersedia membantu kegiatan kami dan tak lupa kami ucapkan kepada mahasiswa KKM UNSERA kelompok 5.

\section{KESIMPULAN}

Beberapa hal yang dapat disimpulkan dari keseluruhan hasil kegiatan kemitraan ini antara lain:(1).Secara keseluruhan program telah berjalan $100 \%$, artinya semua tahap kegiatan kemitraan telah dilakukan dengan sabaik-baiknya mulai dari tahap awal hingga tahap akhir.(2). Capaian luaran dalam hal ini publikasi kegiatan telah sesuai target yang meliputi (1) data berupa persentase hasil observasi pemahaman, persentase hasil angket pemahaman, data perspektif , rekapitulasi angket tanggapan dan saran , dan keefektifan kegiatan pelatihan; (2) publikasi (published) pada media elektronik repositori Universitas Serang Raya.

\section{DAFTAR REFERENSI}

Cresswell, J. (2014). Research design: Qualitative, quantitative, and mixed methods approaches, (4th ed). Belmont, CA: SAGE Publications, Inc.
Gujimar, D. (2016). Penulisan karya ilmiah. Jurnal Asosiasi Penulis, 7(3), 61-74.

Kachru, Z. (2008). Norma, model dan identitas. Jurnal Elektronik, 20(10). Diakses 22 Maret 2008 dari http://jaltpublications.org/tlt/files/96/oct/index .html

Soetarjo. (2014). Penulisan artikel ilmiah. Dalam Sardi, B. dan Warsidi, Z. (Editor). Menulis artikel untuk jurnal pengabdian kepada masyarakat. Semarang: Cemerlang Press.

Wahab, A. \& Lies, A. (1999). Menulis karya ilmiah. Surabaya: Airlangga University Press. 